\title{
Plaquettes Decorated as a Historical Source of Paleolithic
}

\author{
Juan Clavijo \\ Faculty of Geography and History, National University of Distance Education, Spain
}

Copyright $\bigcirc 2017$ by authors, all rights reserved. Authors agree that this article remains permanently open access under the terms of the Creative Commons Attribution License 4.0 International License

\begin{abstract}
This research aims to provide an overview of the phenomenon of plaquettes decorated in the Paleolithic. In order to achieve this objective, the study of the results of different excavations in which these mobile art objects have been found has been carried out, as well as the revision of the theories about this subject presented by different authors, and the analysis of the results of recent technological studies regarding these supports. Finally, a hypothesis which contemplates different aspects, such as the determinants that could have originated this artistic phenomenon, its variability development and its possible uses, is developed.
\end{abstract}

Keywords Paleolithic, Plaquettes, Rock Art, Decorated Pebble, Movable Art, Zoomorphic

\section{Objectives}

The purpose of this work is to present an approximation to the nature of the decorated plaquettes of the Upper Paleolithic, to gain knowledge of the environment, the life, the gestures and thoughts of the individuals who produced them, and, finally, to consider and to discover how were they made and for what reason.

The plaquettes have a double nature. On the one hand, as artistic works, they are subject to study of their aesthetics by the History of Art, and given their status as historical documents, they are studied by Archeology as an archaeological source.

Among the objectives proposed in this study, we find:

- To present an overview of the phenomenon of Paleolithic plaquettes.

- To collect hypotheses and the most important scientific and technical information regarding the reasons for its manufacture and its usefulness.

- To propose new questions.

\section{Historiography and Status of the Question}

Among the interpretations regarding plaquettes, there is the one held by Lorblanchet [22]. Based on the observation of coincidence, he signaled that in places with abundant appearance of plaquettes and movable art, parietal art was scarce, and vice versa. From this, he deduced that decorated plaquettes would play the same role parietal art did. They could be "movable walls". Later, however, the finding of new locations where both movable art and parietal art was found questioned this interpretation.

Later, it was discovered that some plaquettes were transported for long periods and that holes were made in order to hang them. This has renewed the interpretation of "movable walls" in the sense that they could have been placed on the walls, giving them a role as a "replacement" of the mural (the Cave of La Marche published by Dr. Leon Pales and Marie Tassin de Saint-Pereuse) [7]. They have also been found on cave walls as friezes.

According to Delporte [7], the interpretation of plaquettes as "animal-memories" could explain the enigma of why the animals represented on them are not the same as those found in kitchen remains. The author points out that the hypothesis of a radical change in the environment that would have caused a transformation of the fauna and reduced certain animals to a memory is unacceptable. When a Paleolithic group left a region which was characterized by a certain biotype, particularly an animal one, and moved to a different region, it could have carried with it a physical or mental image of the animals that were known to them. This hypothesis would largely coincide with the use of plaquettes as a "movable walls", as it was mentioned before. The plaquettes would be installed in each new location where the group would have stayed along its nomadic path. It could also explain that some plaquettes were transported during an extended period.

Some plaquettes contain tangled figures that are difficult and complicated to observe due to the lines that are interwoven, which are sometimes very rough, requiring adequate illumination and a very patient reading of the strokes to discover the content, in order to isolate each recorded image. Many of the plaquettes' surfaces have been reused, rewritten in successive stages in different times. Therefore, in these cases, this would be a temporary art. In these circumstances, this has led us to think, among other things, that they could be apprentices' plaquettes. They 
would be, therefore, sketches of the Paleolithic artists in the process of learning. It has been pointed out that the decoration of these lithic supports which have exhumed in places of occupation was usually anarchic and with a pronounced ephemeral sense [22].

However, on other occasions such as in Castillo or Altamira, this kind of movable art was deposited in the entrance halls of large decorated caves, perhaps as the result of some kind of ritual at the entrances. The new discoveries indicate the great ubiquity these objects had, perhaps indicating their multiple uses.

Upon observing the collections of fractured plaquettes, Mons pointed out that they appear to have been used for one occasion only, during a single ceremony or ritual, being abandoned subsequently, or destroyed when abandoned, signaling some kind of symbolic sacrifice.

Undoubtedly, the artistic works of the Pleistocene period were part of the culture of the societies which created them. Thus, information within the hunter-gatherer groups was acquired through movement, through nomadism or the movement through the territory, which was an intrinsic activity of this kind of economy. The transmission of this information could have been of verbal or visual nature. This cultural transmission could be recognized thanks to the ethology studies [5] carried out in collaboration with specialists on the study of live bison. The studies signal a load of subliminal information contained in the figure of the Paleolithic bison. The specialists observed different scenes which were represented there, such as for example "young female bison in a waiting attitude" or "old male in attacking position".

According to Valentin Villaverde [28], this ethological component could have been evident through his study of the plaquette collection of the Cova del Parpalló. In particular, he describes several scenes that go beyond the strict lithographic representation, that is to say, a representation of the animal limited to the essential traits of species. He points out that scenes representing pre-coupling, combat, maternity and hunting have been documented. The author compares these scenes with those of other places, such as those representing maternity images at Morin Cave, Mas d'Azil, Laugerie-Basse, Lespugue, Brassempouy, Lachaud and Limeuil. Maria D. Simón Vallejo and others [24] signal the same aspects on their studies of the figure represented on the plaquette located in Gorham's Cave (Gibraltar) in August 2005. The plaquette was located on a projection of the ceiling, at about $40 \mathrm{~cm}$ from the current ground, and represents a deer with antlers that allow us to identify it as an adult male specimen, whereas, taking into consideration the position of the animal's neck and of the horn regarding its back, it seems to be in an attitude of bellowing.

Sanchidrián [22] explains that the production of images carries with it a communicative component. It expresses something. It keeps a meaningful message within the society for which it was created. In this sense, Fortea [8] claims that signs are the graphic expression of ideas that follow seemingly standardized, stable and complex patterns of execution. Likewise, Castro [4] signals that the diversity of forms of expression could have been saved through a communicative artifice or graphic language, through naturalistic images of explicit (animals, plants, arrows, spears) or conventional (signs) meaning to provide non-verbal information (Semiotic function) on the acquired knowledge to coetaneous individuals or to other generations. This author interprets some of the signs on the Parpallo's plaquettes as drawings that would represent ropes and basketry weaves.

Regarding the message presumably contained on the zoomorphic figures of some plaquettes, Delporte states that deformations and disproportions are not mistakes at all. According to him, they were voluntarily made and designed to show real anatomical aspects when these are not clearly visible, for example the correct form of some organs and their arrangement by pairs, such as hooves or horns, forms that would not be apparent on a sideways showing. These disproportions seem to have always been focused on those details considered more characteristic of the animal, or those which defined more clearly their qualities: the bison's hump, the horse's mane, and the ibex antlers.

The reading made by Pilar Utrilla and others [26] regarding the interpretation of the engraved blocks of the Cueva Abauntz is worth mentioning. The authors consider them a sketch, such as a map, of the surroundings of this cave and its topographical details, connecting them to other international studies carried out in the same sense, such as the plaquette of structure 1 from Mezhirichi, on which I.G. Pidoplichcko (1969) [26] recognized "the map of a village with a few huts between mountains, on the banks of the Rosava and Ros rivers, tributaries of the Dnieper river", or the rib of La Rochette (Beinhauer 1986) [26], which could represent a cave, a river and a cliff drawing. On the other hand, these authors also consider the possibility that these blocks narrate some kind of "feat" or "a hunting day". The most interesting question is whether the artists intentionally left this sketch or story so that someone could read them.

Plaquettes have also been found in open archeology sites, far from the deep cave-sanctuaries where the large friezes of the Paleolithic are found. For example, the large boulder at the Étiolles (Essone) site, which was part of an open-aired room excellently preserved and studied, seems to point out that some of these pieces were treated in a way different to that explained so far, being carefully placed with an evident intention of promoting their durability [21].

In Gönnersdorf [25] (Rheinland-Pfalz, Germany), the schist engraved plaquettes covered the ground excavated on a surface of about $50 \mathrm{~m}^{2}$. A study of the themes represented on them and of their initial location at the time of their discovery led the authors to establish a different spatial distribution from those of the mammoths and birds, which belonged to different habitation places. The proposed interpretative hypothesis is that of a seasonal visit to the site by the same groups. 
Several excavations link the decorated plaquettes to homes. José Alfonso Moure [20] indicates that the recovery of 34 fragments of plaquettes in the Cave of Tito Bustillo, most of them engraved or with traces of red paint, was clearly related to the level of occupation of the cave and its homes. Likewise, the author also connects the representations on these plaquettes with the cave paintings in the cave. The same relation was made in the cave of Abauntz [27], where most of the engraved and painted stones appeared [26].

Another example is the study carried out by César González [14], which signals that the patina over the surface of the engraved plaquette of Urtiaga could be a consequence of having been used as a polisher before it was fractured. This study analyzed whether the plaquettes were part of a house, as a bed or as a pavement, as it seems to be.

In her analytical work, María Soledad Corchón [6] highlights the reuse of some lithic supports, before and after the engraving. There are specimens that keep traces of their use in various activities, abrasion and polishing marks associated with multiple multidirectional carvings that indicate that they were used as a wheel for percussion actions while place crosswise/wide-spread, to reduce to dust some material. This use originated the fracturing of the stone. Later, the upper part was engraved and it was subsequently used as a polisher. This indicates that these supports were not chosen as movable engravings, but that broken and discarded objects would have been used as part of the decorations of the economic activities of the social group. No specific determination to preserve this developed art pieces has been established and this indicates the daily use of these pieces. This attitude allows us to point out the possible loss of value of these pieces after their execution and, therefore, it allows us to explain their abandonment on the ground on which the group carried out its daily activities [21].

The reuse of anvils [24] and of color palettes [23] on which engravings were made has been the object of deep technological studies.

Perhaps the site where the reuse of a plaquette or its fragments seems to be most evident could be the soil of Limeuil (Dordogne) from where, between 1909 and 1913, Father Jean Bouyssonie extracted 300 limestone plaquettes of varying dimensions (CAPITAN AND BOUYSSONIE 1924). Tosello points out that the art of this site is primarily figurative (more than 200 animals). These plaquettes have a remarkable characteristic: the two thirds of them are both broken and reddened by fire. The author suggests the phases of this creative and, at the same time, destructive behavior: having collected a plaquette in the vicinity of the site, the artist engraves it and then abandons his work by turning it into a stone for his daily use. Such situation results in a more or less intense fracturing of it, followed by a separation of the fragments. Some pieces (rubified or not), especially those which have multiple overlays, could be reused at different times. An authentic cycle around the act of engraving is therefore established (Figure 1). It should be noted that this sequence could have be consistent with the everyday nature of the act of engraving, particularly for the reused fragments that could have be trials, practices or hobbies and that were later discarded within the site. Would it be possible to recognize on this site the pattern of a relaxed, idle moment, while the artists rehearsed the figures they wanted to engrave?

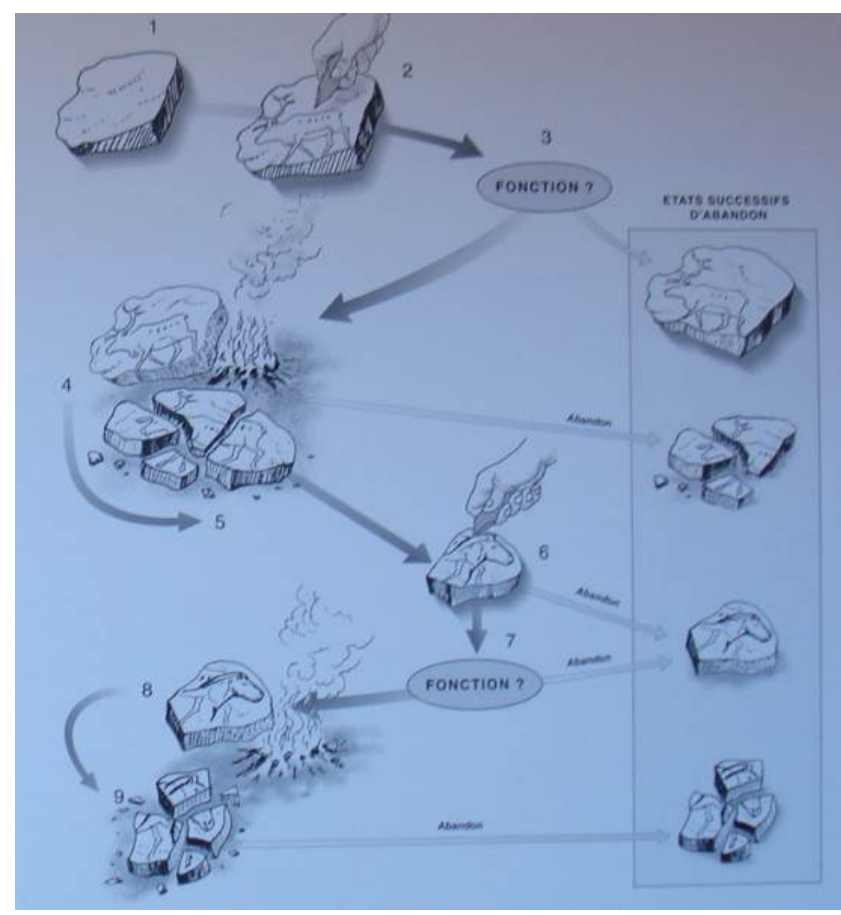

Figure 1. Theoretical scenario of the engraving process. (Source: [25])

Therefore, the plaquettes and the representations they contain must have had, in some cases, an everyday use within the Paleolithic life. In this regard, Arias and Ontañón [1] state that "there are indications that sometimes movable art was a reality fully integrated in everyday life". And, in the same regard, Tosello [25] states that "habitat contexts seem to be a relevant constant, particularly in the case of engraved stones that are always mixed with different kind of remains, fauna, tools and debris from the everyday life. These stones followed a cycle which developed at that very site and that led to a partial destruction, abandoned and posterior reuse of most of them". There are several authors who also express themselves in this regard.

As Gamble [11] explains us, this kind of meetings can leave an archaeological record with a particular pattern. Meetings include the presence of resources that can be transported, such as food, stones and bodies. These materials are part of the action that takes place between individuals when they negotiate some kind of social bond. These materials organize the interaction and determine the spatial structure of the archaeological record. For example, a home preserves the meeting by means of the waste stacked around it while the interaction takes place. The residue sample is sufficiently consistent to last over a whole series of taphonomic processes.

Finally, a very promising finding for the study of movable art is the lower gallery of La Garma [21] [1]. Its peculiar 
isolation conditions are what had made its conservation possible as a true "closed deposit". It is formed by a great amount of human activity remains, mostly fauna bones, as well as stone and bone works, and it also includes several structures such as stone constructions, holes and materials accumulations. The radiocarbon dating attributed the observable part of these deposits to the Middle Magdalenian, around 14,000-13,500 B.P. An important set of Paleolithic parietal representations is associated with this enormous occupation site. Tree enclosures attached to the western wall of the room have been documented. These are built with stone walls and fragments of stalagmitic crust. Next to them, there are several animal figures engraved or painted on the low and inclined ceiling, located immediately over the structures. It could be interpreted that at least part of the representations were made from the interior of these enclosed spaces. The 17 decorated plaquettes found are in fact stalagmite specimens and flat limestone fragments that form the soil of the cavity. There is no greater immediacy in the collection of these resources. There is a recurrence of the decorative idea, that is, a reuse of the supports. The association of these objects to an exceptionally well preserved archaeological context on the surface may allow us to propose verifiable hypotheses. This occupation site includes several remains of human activity, with important concentrations of pieces of furniture, parietal art and structures built inside the cave. Several testimonies lead us to believe that these plaquettes were developed, used and finally discarded here, remaining as part of the dense tapestry of remains that constitute the habitable soil of the lower gallery of La Garma.

\section{The Plaquettes, Source of Historical Information}

Presently, the research on Paleolithic movable art continues to advance in different fields. Technical research in the light of the latest scientific advances, as well as new pluri disciplinary methodologies and the development of Cognitive Archeology, make it possible for us to visualize what has been discovered so far with new approaches. The engraved plaquettes of the Paleolithic present a double enigma: on the one hand, their origin and the motives behind they development are unknown. And on the other, which was their meaning.

\subsection{Artistic and decorative techniques}

The most common techniques used to decorate the plaquettes are the engravings, relieves and incisions. The paintings' chromatic range covers a wide spectrum, with black, yellow and red dyes. The application techniques vary between continuous lines that outline the contours of animals and signs, flat paintings that cover either the whole anatomy of the quadrupeds or only the front part partially, and even combinations of pigments and different engraving methods that highlight the zoomorphic silhouettes.
At a quantitative level, the pieces with designs based on incisions are the most common. The most adequate instruments for working hard substances are those made in Silex, such as chisels or splinters. The traces they made are of two kinds: engravings of symmetrical section in $\mathrm{V}$ and in $\mathrm{U}$, which could provoke a dissymmetry in both variants depending on the attack of the hammer on the plaquette and the way of the incision (at an angle which was inferior to a straight one).

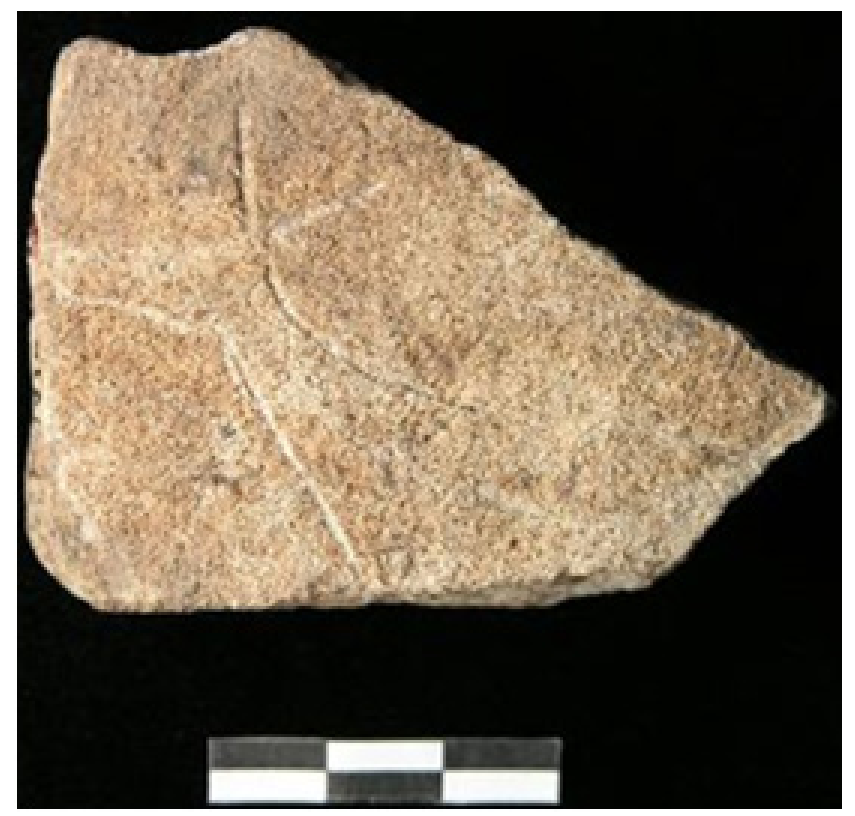

Figure 2. Plaquette of the Upper Magdalenian, found in the Cave of El Parpalló, inventory Do00131, Length $=67 \mathrm{~mm}$; Width $=50 \mathrm{~mm}$; Thickness $=16.50 \mathrm{~mm}$ (Source:

http://ceres.mcu.es/pages/Visor?AMuseo=MNCIA\&Ninv=DO00131\&acci on=4)
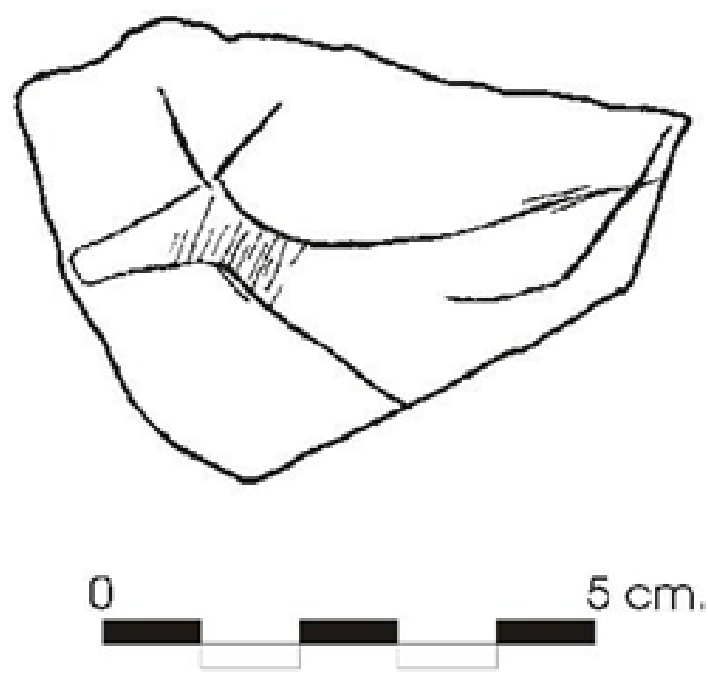

(Source:http://ceres.mcu.es/pages/ImageServlet?accion=4\&cabecera=N\&t xt_id_imagen $=2 \&$ txt_rotar $=0 \&$ txt_contraste $=0 \&$ appOrigen $=$ )

Figure 3. Copy of the engraving on the engraved plaquette of Upper Magdalenian found in the Cave of El Parpalló, inventory Do00131, Length $=67 \mathrm{~mm} ;$ Width $=50 \mathrm{~mm}$; Thickness $=16.50 \mathrm{~mm}$ 


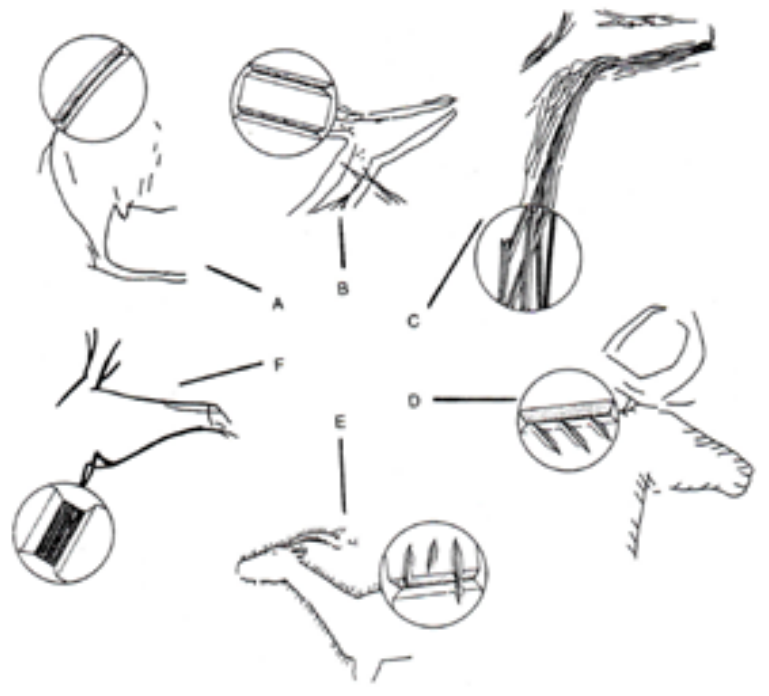

Figure 4. Types of engraving: A/ single stroke. B/ double stroke. C/ Fluted multiple stroke. D/ Simple inner stroke in a "wire of thorns" style. E/ Clumsy outer stroke in a "threadbare wire" style. F/ Grooved, broad and shallow, close to the line. (Source: [22])

The most common styles for the engraved strokes detected in the plaquettes are the simple or monolineal stroke, where the silhouetting of the motif is made with a single stroke; the double or bilinear stroke, wherein the contour is mark by two parallel strokes; the multiple stroke, which consists of outlining the design with the succession of small short subparallel incisions that do not form a closed group, so that there are free spaces between lines; the grooved style, in which the grouping of the strokes is greater and the support can hardly be seen; the wire of thorns, in which the simple engraving is decorated with more or less perpendicularly small strokes, has two versions: the simple inner stroke (the perpendicular smaller strokes start at the outline towards the interior of the figure following a certain organization) and clumsy towards the outside (the smaller strokes are disorganized and point towards the exterior of the figure mostly); and the grooved stroke, which maintains two angles in its section and it is wide and shallow, and when the strokes followed, the bifid aspect at the bottom of the incisions may be noted (Figure 4).

Sometimes, the plaquettes show deep engravings. Although most of them have finely drawn motifs, their visualization may be very complicated and requires adequate lighting conditions, since the images are overlapped and entangled on many pieces.

\subsection{Variability}

Another aspect to consider is the great variability that we find on the Paleolithic images. It is possible to appreciate that different engraving techniques and different perspectives were used simultaneously.

Although different explanations exist, probably all of them may be valid to explain this remarkable variety (learning, breaking of tradition and other social hypotheses, such as exchange and information networks). We still need to ask ourselves about the reason why different techniques were used in parallel. Would each artist choose to do it that way? Are they actually conventions that are repeated for certain representations?

Nevertheless, the technological studies on plaquettes point out, as we will see in the next point, that all this observed formal variability is part of an operational chain probably established by specialists.

\subsection{Operation Chain}

The operational chain of idiomorphic and zoomorphic engravings in movable art has been deeply studied and described by some researchers. Regarding zoomorphic figures, Carole Fritz [10] proposes an outline thanks to an exhaustive work on bone supports. She presents a model that can be split into several stages necessary for the development of a movable art object. The first transformations undergone by the support can be defined as the modifications suffered by the surface (preparation). The next stage would be decoration. The engraver would establish the space reserved for the decoration; define its graphic area as well as the state of the surface and its quality. The conditioning stage would be a few discreet incisions, destroyed mostly by the final execution. These sequences have been recognized in objects from the Arancou (Pyrénées-Atlantiques) and La Vache (Ariége) sites.

Carole Fritz has also revealed the mental schemes behind the formal construction by recognizing sequential processes in the execution of the figures. Thanks to the microscopic observation of the overlapping of the strokes, it is possible to identify the sequence models of the acts performed for the figures development. The breakdown of these elements in a sequence reveals operational constants: in all species, the head contour is the first thing which is engraved. Then, the back or chest is drawn, while the third element is the anterior extremity, located after the chest. In the fourth place, the belly line is performed, followed by the hind limbs, the rump and finally the tail. This operational record shows that Magdalenian artists constructed their animal silhouettes, regardless of species or orientation, starting with the head and ending with the rear. The internal attributes have an immutable and predictable operational sequence: they are always engraved after the contours; the sensory organs precede the coat and, finally, the signs. The contours and the internal attributes present different execution modes that justify their differences in graphic status. Whatever the animal, the Magdalenian artist followed a precise order in the operational chain and in the construction of the figure. These operational sequences are a reflection of relatively strict mental schemes that govern forms. However, this operational scheme is not completely immutable: the microscopic examination of the technical sequences of two objects from Morin Cave present actions that differ from 
those observed on Magdalenian supports. Although these comparisons are very specific, they suggest that there was a profound change between Magdalenians and Azilians. According to Carole Fritz, this rupture seems to be clearly cultural.

This pre-established plan could be confirmed by the works of María D. Simón Vallejo [23] who goes more deeply into the line of authorship, presents differences on the order of execution of the engravings and analyzes the differentiation of the two creative phases. The first would suggest a number of figures and its adjustment to the support and the second would be the execution itself. Thanks to the microscopic observation of the overlapping of the strokes, we can identify the models of sequences of gestures carried out for the development of the figures and of the idiomorphs. This technique reveals an operational constant: for all species, in general, the head's contour is first engraved, then the back or chest is drawn, the third element is the anterior extremities, which are located after the chest. In the fourth place, the belly line takes place and then the hind limbs, the rump and, finally, the tail. This matches the sequence of Carole Fritz's studies which are mentioned above.

Likewise, with the engraving of signs, Fortea [8] suggests and argues that the traces follow a plan which was predetermined by the artist (Figure 5). These programmed and standardized compositional patterns are repeated on the analysis of plaquettes with cross-linked motifs with internal divisions, characteristic of the Parpallo site. According to the author, as they are a precise chronological indicator on the sequence, because of their being motives well ascribed to the Magdalenian period, they present a marked uniformity in the representation and have a complex internal structure which points out to a formalized and repetitive concept on the execution. In her opinion, the author explains, the organization of the space for the development of signs is programmed from the beginning. On the first place, the boundaries of the reticulate would be marked and the intermediate spaces would be reserved. Then, the horizontal and vertical parallel lines would be engraved, or vice versa. The following step would be the repetition of the strokes that, for different reasons, would not have been sufficiently marked, and finally the boundary strokes would be re-done. To conclude, the author states that we are before a development process that has nothing to do with chance or pure "improvisation", since it always follows a preconceived and thoughtful development scheme, voluntarily marking that which the artist wants to highlight and rectifying any engraving mistake or accident to reach the desired artistic, utilitarian or ritual goal.

According to numerous researchers, to ensure the continuity and transmission of the social codes which governed these art forms (and the strict operational chains previously mentioned), the production of movable art during the Magdalenian period may have been closely controlled by a social group and, as a consequence, it may have been the product of a specialization of individuals in charge of its realization. From this hypothesis, Carole Fritz states that learning must be the most adequate means to account for the transmission modes within the groups. And finally, she declares that, when applied to the Paleolithic, the notion of learning is still an enigma. Will we ever meet their particularities? The notion of learning generates more questions rather than specific answers, and in the study of movable art, training in engraving techniques has long been considered, but it has never been truly addressed, and therefore it has not been proven.

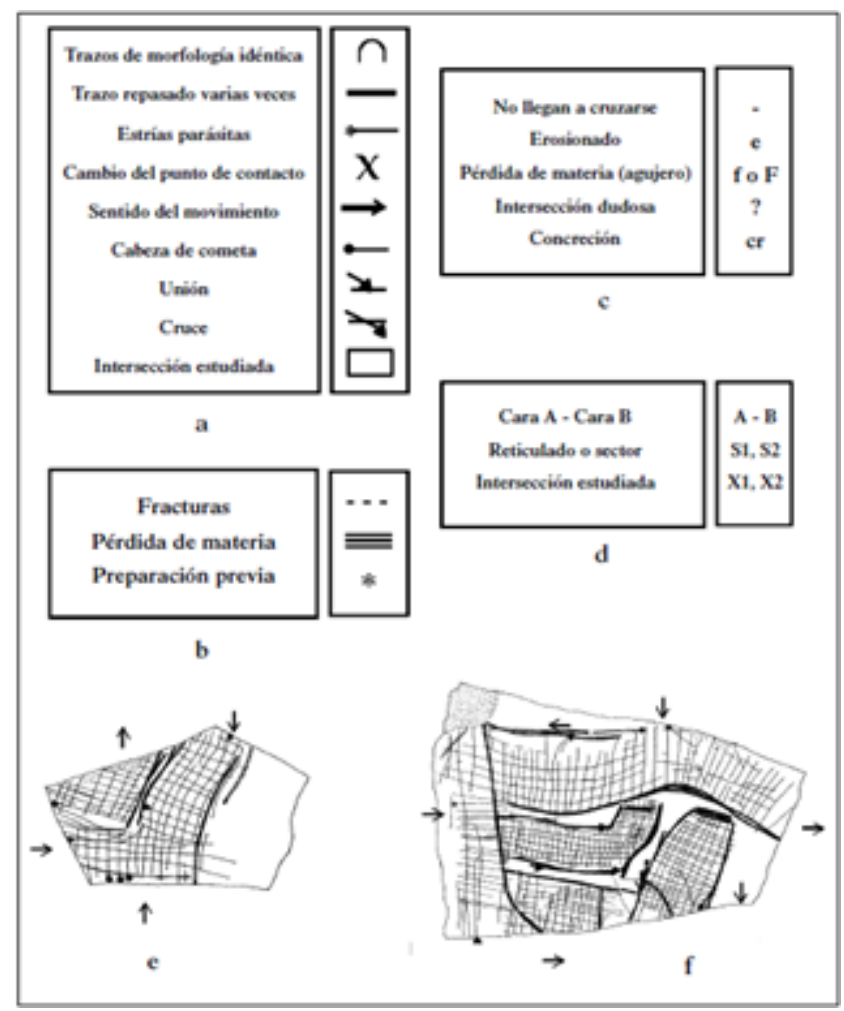

Figure 5. a and b: Graphical conventions applied to technological copies (b: Surface's state); c: Abbreviations used in the engraving order tables; d: Abbreviations; e and f: Technological copies of 19993 (e) and 20189 (f) (Source: [9])

According to numerous researchers, the operational chain is also very important in order to explain why and how this kind of art expanded and what were the causes of its success and transmission. The support of this art has been, above all, a raw material which had to be searched, acquired, transformed, and finally engraved. Without these different stages, the work of movable art would not exist. Clive Gamble [11] declares that acts of a technical nature are social acts, an idea that facilitates their "sale" by the artist and their acceptance by the rest of society. What converts man-made objects into symbols is their contribution to the integration and restructuring of human activity, once they are not part of their creators anymore. Leroi-Gourhan (Quoted by [11]) also states that technical acts are, at the same time, social acts. This social fusion must necessarily occur, since many operative sequences presented as ways of doing and acting, as rhythms of the collective tradition, are necessary to ensure the survival of art. It is there where the flexibility of the 
operational chain lies, defined as socialized action applied to matter (Lemmonier, Schlanger, quoted by Gamble, 2001). Therefore, the operational chain is more than a muscular memory of how things must be done without having to think about them. What matters are the acts themselves and the relationships they provide through time and space.

\subsection{Context of the Findings}

It is this aspect of the interpretation in relation to the context that Arias and Ontañón precisely address [1]. They explain that the concept of context is not limited to a mere spatial connection, but that it also incorporates the notion of the existence of a functional or meaningful link. Therefore, the context would be the feature that gives archaeological significance to an object. In the present case, the graphical movable expression, the context may provide revealing perspectives in order to address the complex problem of meaning. The finding of decorated objects at the sites, and the elements to which they are associated, can allow us to link them to certain activities. From this point of view, it is easier to study the context of movable art rather than that of rupestrian manifestations, whose relationship with the rest of archaeological information is usually problematic. It is in this way that these two authors have focused their magnificent study of movable art on the lower gallery of La Garma [21], in which the peculiar isolation conditions have permitted to study in a very particular way the remains of human activity in its primary state, to which an important set of parietal representations and objects of movable art is associated.

At present, new technologies lets us carry out new approaches regarding the treatment of the information collected during an archaeological excavation. As we know, the extraction during excavation implies the destruction of the registry. However, we can "sweep" the lower layers during the extraction by means of laser sensors (terrestrial LiDAR), in such a way that when processing the data with a specialized programmer, we can virtually reproduce the deposit in its original state and try to examine and find new relationships between the represented artifacts, which were, until now, impossible to find. Moreover, through Geographic Information Systems, we can be cataloged and georeferenced the artifacts found per layer.

Ethnographic social concepts could be applied to these virtual models in order to try to clarify some sets. As indicated by Gamble [11], meetings include the presence of resources that can be transported, such as food, stones and bodies. These materials are part of the action that takes place between individuals when they negotiate some kind of social bond. These materials organize the interaction and determine the spatial structure of the archaeological record. For example, a home preserves the meeting by means of the waste stacked around it while the interaction takes place. The residue sample is sufficiently consistent to last over a whole series of taphonomic processes. Some studies have already explored the exact location of all the elements found during the excavation, such as Balbín and Alcolea [3], but the relationship between them and the detected households has not been analyzed.

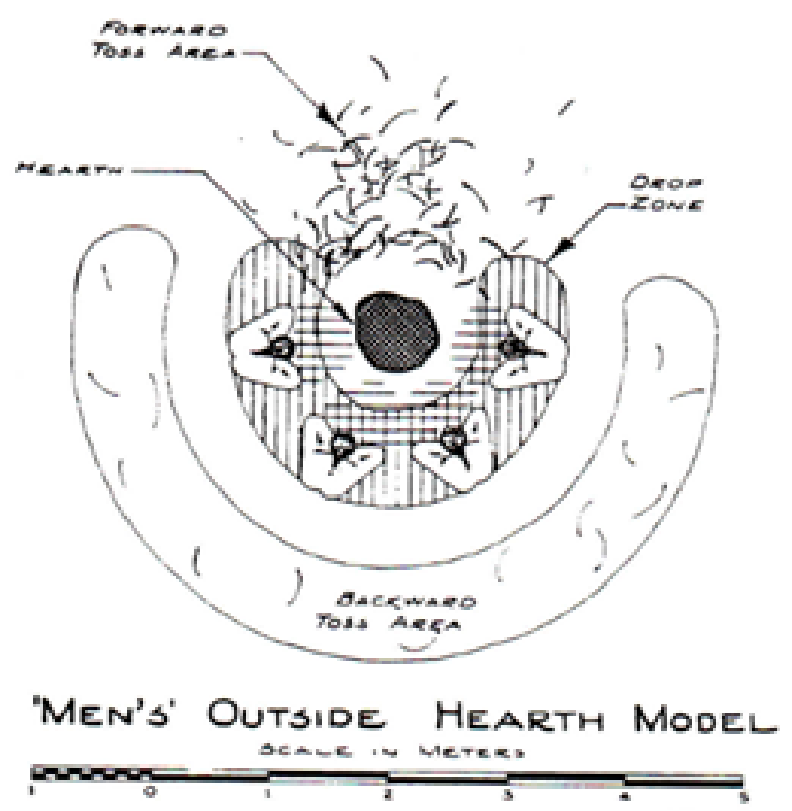

Figure 6. Spatial schemes that generated around households. Based on observations of the Mask Site in Anaktuvak Pass, Alaska. (Source: BINFORD, quoted by Gamble [11])

In his study of the Nunamiut, Binford offers an ethnoarchaeological example of the conversational group. This case comes from one of the hunting stations known as Mask Site. In this place, some craft-related activities were also developed. When the hunters sat around the fire forming a horseshoe figure (Figure 6), the predominant activities were conversation and food, although they sometimes also played some games or made some masks. Conversational groups rarely included more than 4 or 5 people. Binford gives us further information about the spatial distribution of food debris thrown to the ground while being eaten and of other abandoned waste thrown while making the masks. The waste was treated differently according to its size. The small fragments were dropped to the ground in the same area where the men sat, and the bulky ones were thrown over the fire, if there was no one sitting in front of the man, or over the should, towards the back. The area of accumulation of the residues that were dropped forms a ring located $50-100 \mathrm{~cm}$ away from the fire. The zone of accumulation of residues that were thrown forms a wider ring located $2.25-2.75 \mathrm{~m}$ away from the fire. The Binford's model provides us with an instrument of spatial analysis that can be used to evaluate possible relationships between households and the arrangement of decorated plaquettes in the register, defining a social pattern recognizable as a meeting, in which to pass time the men engraved zoomorphic and idiomorphic anatomies on fragments, which are now thought to be scattered around the room forming part of the registry. It would be an idle moment during which they would dedicate themselves to pass time chatting about the hunt while developing with their hands engraving practices, reusing [14] 
for it small discarded fragments or small slabs from the soil of the surrounding grounds and, in turn, abandoning them once the sketch was finished.

\section{New Proposals}

\subsection{The Petrifaction of Art}

During the Upper Initial Paleolithic, progressive selection of the raw material used to manufacture lithic tools took place. This caused the artifacts to be more durable and effective for their function.

On their side, Paleolithic artists noticed how the passage of time deteriorated their artistic representations made on perishable supports such as leather, vegetable fibers or wood. In the same way as they did for the manufacture of their lithic tools and at the same time, they must notice the possibility of selecting raw materials that best fit their needs. Around $35,000 \mathrm{BP}$, these necessities were a longer duration of the objects, probably due to the growing communication networks and greater social complexity, as seems to be evident by the seasonal migrations. The idea of using more durable media could have expanded with some ease given the social necessities of obtaining a more effective and permanent expression system which facilitated communication between the groups that would periodically meet. They may have been able to develop new operational chains to work on new supports (ivory, antlers, bone, stone) and thanks to this new work system, new tools capable of a more precise carving would have been designed [7], which, when applied, would allow new types of representation, such as round-shaped figurines on ivory and other pieces of movable art.

It is for this reason that the so-called "Paleolithic artistic revolution" was not an explosion of sudden art, but could have been related to a change in the choice of materials for the supports. The Paleolithic authors selected more resistant materials to express their artistic manifestations, which are the only ones that have reached our days, which have generated the incorrect notion of "revolution". Thus, it could be a "differential conservation" [7] applied in this case to the raw materials that constitute the supports of the artistic representations.

\subsection{Communication System, Natural Message}

The plaquettes could have been the physical transport of natural concepts or even a graphic communication system. There are many indications that point in this direction, such as the signs of wear and tear due to transport, the value given by its creators (who carried their weight for years), the message inserted in natural key (visualized by Ethology and Zoology), the probable need to improve communication with other groups due to growing social networks and greater social complexity, the conventions that were repeated in large regions, etc. But only a few plaquettes show symptoms of having been transported. Most of them were discarded, broken, and sometimes reused to be re-engraved or used as a sharpener. On a few other occasions, a real eagerness to safeguard these objects can be described. Probably, the explanation for this multiplicity of findings corresponds to a diverse variety on the use of the same, although the desire to transmit something in the same way is always present in the background, as expressed by Sanchidrián [22] when he explains that "the production of images carries with it a communicative component, it expresses something, it keeps a meaningful message within the society for which it was created". We must not forget that one of the main characteristics of the Paleolithic movable art is its pragmatism: practically all the utensils are vulnerable to becoming part of the artistic collection, and at the same time, any support can be reused as a sharpener, house boundary, pigment source, etc. Art during the Paleolithic period was probably understood as utilitarian [19].

On the other hand, it seems too much of a coincidence for the Paleolithic art to appear as it is usually described, so overwhelming both in quality and quantity over a period of time and space which in turns overlaps with the time and area in which Modern and Neanderthal men had to coexist during a period of 13,000 years. I believe we should ask ourselves whether this meeting had anything to do with the genesis of art.

\subsection{From Plaquette to Wall}

Some plaquettes have been found to be intimately related to rock paintings, either by their arrangement, the same conventions used for the figures, the use of the same elements and techniques for the elaboration of pigments or by findings in which this is evident, such as the one explained in La Garma, where the presence of decorated plaquettes on the floor can be directly related to certain room structures from which the cave's nearby walls were decorated. On other occasions, plaquettes with perforations to hang them have been found. They are in accordance with the idea of "movable walls". With this evidence, it is not surprising to think that there exist a connection between this movable and rock art [18].

One of the signs which would support this intimate relationship between parietal art and plaquettes engravings can be found in the Mas d'Azil cave (Ariège), in the Breuil gallery, where engravings and parietal paintings are united: on the vertical of a bison engraved in the vault, there was a large boulder, still attached to the ground, decorated with a horse, which was a contemporary of the Magdalenians. Only a few centimeters separate the horse from the bison, both of which have comparable dimensions, style and technique. The configuration of the space and the isolation of the figures seem to suggest that these two animals were closely related in the mind of their creator (Figure 7). Another example can be found in the Bédeilhac cave (Ariège), which provides a 
good example of the close relationship between decorated walls and movable sets. The cave contains an important set of parietal art and several areas of marked Magdalenian occupation, which supplied almost a thousand decorated objects. The originality of this movable art consists in the almost constant use of the morphological characteristics of the rocky support. This phenomenon is not present only in Bédeilhac, but it reaches in site extraordinary proportions (TOSSELLO, 2004). Another example can be the faithful reproductions of does engraved both on plaquettes and on the rupestrian art of the castle or Altamira (Cat. No. 11 and 82) [19]

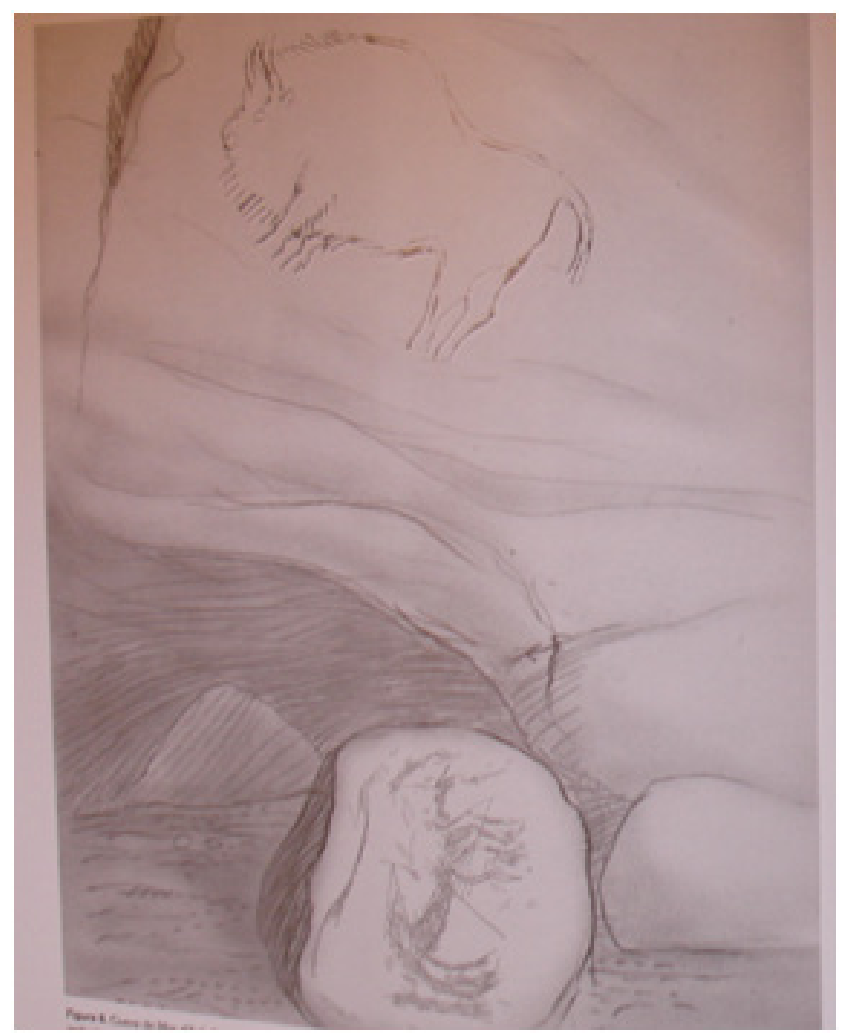

Figure 7. Sketch of the position of a rock which has been engraved with a horse on a bison's vertical on a wall. Cave of Mas d'Azil, gallery Breuil (Ariège) (Source: [25])

After many centuries of success (Parpalló's archaeological record are 14,000 years old), the plaquettes could have lost their practicality, perhaps due to the expansion of the social networks and their communication and exchange systems. Perhaps an evolving, more complex society would have required new ways of transmitting its cultural message. Paleolithic men might have needed a better not movable support, and would have gained a greater expressiveness due to the new support's size and duration. This would have implied transmitting the zoomorphic and idiomorphic figures of the plaquettes to the walls of the so-called "shrines" by means of engravings and paintings. The development and application of specific tools and techniques to produce the figures on the plaquettes could have given origin to other artistic manifestations, such as parietal representations, which share both the conventions and the engraving techniques and the perspective, in the same way the plaquettes do. In general, dating indicates that the tradition of representing zoomorphic figures on plaquettes is took place before the tradition of painting them on walls.

The relationship between parietal art and the movable art of plaquettes could have had two main aspects:

- Training: the plaquettes were used as a test prior to the parietal manifestation.

- Reproduction: the plaquettes were used to transport the figures representing animals to be able to subsequently develop an exact replica of this figure on walls.

However, these two uses do not cancel the hypothesis of the plaquettes having other objectives per se, as I will indicate later.

These relationships could be initiated in the so-called outer "sanctuaries", since dating of these indicates that they were probably the onset of the tradition of wall representations. As Villaverde [29] points out, it is necessary to collect data about the new findings in order to offer a more adequate interpretation.

In these discoveries, located around the Duero Valley, an outdoor parietal wall of great importance has been found [8] [15]. Hundreds of schist and slate blocks have already been found where figures of animals with clear Paleolithic conventions are represented by means of various engraving techniques. Before these discoveries, most classical scholars tended to regard Paleolithic parietal art as an art linked to the world of subterranean depths. Rupestrian art rarely appeared in shallow caves, and the majority of the most important sets seemed to agree with the idea that the Paleolithic artist deliberately sought the obscure parts of the caves to capture their creations and drawings. In this way, Paleolithic art would have had two expressions: one loaded with spirituality and a strong religious content, which is the underground parietal art; and another one of lesser spiritual load, essentially decorative, developed on objects of daily use and associated to habitable places, which is the movable art. The "uncomfortable" cases were located in the middle, those paintings or engravings located at points slightly removed from the entrance of caves and clearly linked to habitable places, or in the case of movable art, made on objects which lacked functional value, such as that of plaquettes.

The new findings added to the classics show that the Paleolithic art of Southwestern Europe contains such a diversity of supports and solutions that their assessment requires the admission of the existence of not only a diverse number of sites, but also of the probability that the dualistic explanations linking the sacred to depths, and the secular to the external or daily life, might not be certain. Therefore, the rupestrian art was performed both outside and inside of caves, and the movable art took place in the same places and in others.

If we accept as a message the representations of zoomorphs and idiomorphs on the plaquettes and the will of 
the Paleolithic men to preserve both their artistic tradition and some concrete representations, it is possible to think that these people took the next step to transport both their message and the support that transports it to walls in order to give better access to a growing number of individuals and to allow this artistic manifestations to have a longevity unknown to them until then, and in some cases, to guarantee the inaccessibility to them in order to avoid their possible deterioration, as it is the case of the Lascaux cave [17] and its Hall of the Bulls in which the figures appear about $4 \mathrm{~m}$ above the ground. Those who created those images must have built some kind of medium in order to reach that height, such as a large platform (painted uros are $5.5 \mathrm{~m}$ long) or a series of mobile platforms, probably made from trees trunks tied together with ropes. To carry out this kind of work, a detailed plan of the operation must have been necessary in order to carry out the painting subsequently.

Considering all that has been mentioned, it is possible to think that some plaquettes discovered there may suggest that they could have been made as a preparation for the great motifs of parietal art, the necessary tests to frame these objects on the new support. This reminds us of the system currently used in arts schools: to paint a mural it is necessary to develop it on a small scale first in order to guarantee the proportions. On the Paleolithic, this scaling or sketch could correspond to the plaquettes. The species transported on the plaquettes is the one that would possibly determine the choice of the roughness of the cave wall that would be more adequate to the represented animal.

In other situations, the plaquettes have been found placed vertically on the surface of the walls of caves, with zoomorphic images visible, which supports this hypothesis.

This approach, which is difficult to verify, could be verified or refuted in light of the new results obtained from technological studies of the engravings and paintings found on walls and their comparison with technological studies of the engravings and paintings found on plaquettes, which could aid us in obtaining the operational sequences of both and deduce new relations.

\subsection{Explanation of the Variability by Accepting the Specialist}

It has been pointed out that a probable control by a graphic expression elite during the Paleolithic must have submitted both the operational chain and the formal definition to a strict unity that would not give place to the appearance of a possible variability, because the specialization does not give answers regarding how the innovations took place. But the truth is that, within the register, we find a great variety of representation techniques at the same time (different types of engraving, painting), as well as multiple conventions, forms and perspectives. Therefore, somehow, the individual creativity was expressed over the centuries, escaping the terms established by the elite that imposed them. How can this be explained?
To distinguish these deviations from tradition or variability, it would be necessary to compare the archaeological pieces and establish a list of well-defined and differentiated technical characters for the whole set [10]. The factors considered original or peculiar to a singularly creative artist would be evident among the static operational chains. As possible examples of this, we would find opposing factors, such as the framing criteria, as unusual as that of Fontarnaud's deer, or the peculiarity of certain themes, such as that of the Enlène's grasshopper.

A possible mechanism, among others, that could have given rise to variabilities or changes in the operational chain that can be seen in some graphic representations of the Paleolithic could have been the breaking of the tradition, that is to say, the sudden disappearance of the specialists-artists:

\section{A Dramatic Event, the Death of the Artist}

The Upper Paleolithic period comprises almost 20,000 years, that is, about 700 generations of individuals, with an average longevity of about 30 years. This period must also have been an insecure era for the humans. Different accidents, such as falls or severe blows, would inexorably cause an agonizing death. Animals, hunting hazards, diseases and climatic fluctuations could have catastrophic demographic effects that would interrupt the life of one or several individuals of the same group at any time. If we accept as valid the hypothesis of specialization, of the existence of individuals specifically dedicated to the making of decorated plaquettes, we would have that, on certain occasions, their premature death would probably have caused a fracture in the transmission of the information that was necessary to repeat the operational chain in an exact way. This proposal offers three main assumptions of what could have happened after the unexpected death of the artist:

- Continuous Tradition: The specialist has enough time to transmit all his knowledge and, therefore, this does not cause changes or variability within the traditional operational chain.

- Partial Tradition: The specialist transmits some of his knowledge to apprentices and, therefore, this generates small changes and variability, without a real modification of the operative chain. As trainees would have been trained during a sufficient period of time and would have had examples left by their mentor, the new specialists would be able to adjust and replicate quite accurately the previous tradition, in this way covering many of the traditional aspects, but introducing some changes or absences.

- Fractured Tradition: The specialist does not transmit any of his knowledge. Therefore, as a consequence, there would be great changes and great variability. This results in the following possibilities:

- $\quad$ Copy and learning: The rest of individuals would decide to imitate what the specialist did, through the observation of the operational chain while the individual was still alive and the 
objects manufactured then. When initiating the production sequence, they would produce errors or additions with respect to the previous tradition, which would result in different representations due to the execution and its conceptualization or mental elaboration. The changes produced on the operational chain would originate different forms, which could be considered correct and would be socially successful, which would originate a new tradition, or they could be considered an error when considering the previous tradition, and would therefore be rejected. This would force the new specialists to continue the imitation through trial and error.

Cultural fracture: The operational chain is lost, and the surviving individuals are not capable of imitating the gestures or of finding objects manufactured by the previous tradition in order to imitate them. This would require a new beginning through the use of social networks, to create a new culture based on other tribes, or been self-taught, which would originate a new tradition. If not, the individuals are at risk of running out of lithic elements/artistic representations and losing their competitiveness in their natural environment, which in extreme cases, would make them disappear.

In the field of lytic industries, a great number of researchers have widely spread the notion of variability in relation to lithic sets [11]. Mellars states and discusses the debate between Bordes and Binford regarding the reasons of the variability found on the Musterienses sets. Today, this debate has been expanded, as Mellars also explains, in order to include more sophisticated settlement systems and mobility models that have an effect on the deposition of different types of objects and on the use of techniques that are size specific. Mithen points out that variability could also be explained by means of the cultural transmission schemes and knowledge-related aspects. The proposal of a variability originated on the tradition's fracture could be another option used to explain the variability and the mutations on the operational chain.

\section{Conclusions}

\subsection{Multiplicity of Circumstances, Multiplicity of Uses for the Plaquettes}

From all the above mentioned, we can claim with some reason that the plaquettes were not developed for a single reason, but that there were different situations that made their development possible by the people of the Paleolithic period. That is, they are probably the result of a wide variety of uses. On the other hand, the represented iconography may have not maintained the same meaning throughout the Paleolithic. It could have evolved in terms of content, similar signs with different meanings could have been adopted, and therefore, it is not necessary that a single explanation exists to explain their creation. For example, the commercial logo in the form of a bull which is an Osborne trademark and symbolizes an alcoholic beverage, has been transformed into a symbol that identifies Spain.

After the initial discoveries, different theories were proposed regarding the association of art, both rupestrian and movable, interpreting the deep caves in which such manifestations were found as sanctuaries, whose possible rituals have been widely covered in works such as that of Lewis-Williams [16]. However, while rupestrian art continued to be almost exclusively linked to caves, in the light of new discoveries, the pieces of movable art offered a new horizon not imagined by anyone until then given their everyday use during the Paleolithic period, made evident by the great ubiquity of the findings. Over time, even the rupestrian and subterranean ritual art had to be revised after a great number of prints and paintings were found outdoors, over walls touch by the sunrays without difficulty [2].

The decorated plaquettes answer to the diverse uses their creators gave them: movable walls to remember their animals-memories, sketches used to learn the process of this artistic manifestation, rituals in sanctuaries through the process of fracturing a plaquette image, a communication system containing information about the fauna of the environment, maps or legends or stories about feats. The plaquettes were susceptible to being stored and preserved, or transported and exposed thanks to holes from which they would probably be suspended by ropes, they could have been markers for certain areas or totems for a certain group, a way to pass the time at home while enjoying a good talk. They were occasionally made reusing anvils and color palettes, stone fragments from home or any material that was near [13], and all this in close relation with rupestrian art, with which it shares numerous conventions, styles and pigments.

To all this, it must be added a presumed incongruity: according to the technical studies, there seems to be a certain sequence that was followed when representing the zoomorphs and ideograms, and this sequence could indicate a control over these realizations. This means that there exists a possibility of them being created by specialists, but in that case, how would they fit in the everyday use we they had? If they are the work of specialists, it is difficult to understand how they can be found in such ambivalent situations. Therefore, it is clear that there is a need to expand the technological studies on these supports, in order to gain more information. Perhaps, we will discover that there were different and parallel operational chains, or that for each temporal period a particular operational chain existed. In any case, it is necessary to expand our knowledge base in order to be able to better comprehend this phenomenon and to advance in its interpretation.

On the other hand, it is possible to think of an example that 
could answer the enigma or the incongruity found. But to accept it as valid, it would be necessary to discover these different operational chains. What I am trying to say is:

Let us take as an example the crucifix of the Christian religion. We can see a church's crucifix that has been beautifully carved in gold, probably made by the hands of a goldsmith, while around the neck of many Christians we can find a crucifix also made of gold or silver, manufactured using a mold. Even better, someone could have carved a cross to use around his neck. The creativity of the individuals leads us to think that the specialist's operational chain does not have to be the same one followed by the user who has carved a crucifix. This is the reason why this example would only be valid if, upon widening the analysis, we discover different ways in which the representations were made.

It should be noted that some research may already indicate this. The presence within the same register of plaquettes engraved with different types of strokes, different engraving techniques and different perspectives is not so rare. In this sense, Corchón [6] states: "As far as style is concerned, it can be said that a great deal of the animals represented in the Middle Magdalenian period share the same graphic models characterized by the naturalistic treatment, the systematization of the iconographic schemes and the statism of the subjects. However, in sharp contrast, there exist unfinished sketches and zoomorphic forms, and naturalistic anthropomorphic forms that accompany other stylized or schematic treatments, even on the same supports. This coexistence of different stylistic procedures and concepts within the same stratigraphic section, challenges the validity of the usual stylistic comparisons". And in this case, it could show that there were actually individuals who made their own engraving (crucifix) without following the strict order established by the specialists. In the same sense, many researches state the same ideas Corchon does. They can notice sketches and errors coexisting with "more naturalistic" forms even on the same piece. So far, the explanation for this fact was the one that referred to the learning of the next generation of artists, but this explanation does not provide an explanation about how the innovations could be produced within the established operational chain controlled by these artists [10].

Sanchidrián [22] provides us with another example: when studying Torre's tube, Barandiarán (1973-1984) was able to identify, due to the superposition of the motives, three stages within the graphic process, which did not follow a "regular" scheme from our point of view, in which the engraving was made, let's suppose, from left to right, organizing the figures and covering the surface (model explained by Carole Fritz in the section Operational chain). Instead, it was made by jumps, reserving intermediate holes in which the most complex designs where finally incorporated. The same - the coupling of the motifs in a universe defined within the mind of the artist - has been observed in other movable works. This example could show that the operational chains were not immutable. Some artists of the Paleolithic conceptualized their works in other ways and developed them in turn following a scheme that was different to the one established by the specialists.

Another possible evidence that could show a self-learning technique in order to imitate the works of previous traditions can be found in the study on the engraved plaquette of Molí del Salt [12], whose authors thoroughly detail the entire engraving process of said plaquette and state that during the engraving, formal processes of correction and structure took place for the composition of a single representation.

\section{REFERENCES}

[1] ARIAS, P. y ONTAÑÓN, R., La Materia del lenguaje prehistórico: el arte mueble paleolítico de Cantabria en su contexto. El contexto del arte mobiliar paleolítico en la región Cantábrica, PubliCan Ediciones, 2005.

[2] BALBÍN, R., La Materia del lenguaje prehistórico : el arte mueble paleolítico de Cantabria en su contexto. Los cazadores de la Cantabria glacial y su expresión gráfica, PubliCan Ediciones, 2005.

[3] BALBÍN, R. Y ALCOLEA, J. J., Arte mueble en Tito Bustillo: los últimos trabajos, Revista de Prehistoria, Historia Antigua, Arqueología y Filología Clásicas Veleia, 24-25, pp. 131-159, 2007-2008.

[4] CASTRO, Z., Información gráfica en plaquetas del Parpalló: consideraciones sobre inicios de tecnologías vegetales CYPSELA, VIII, pp. 15-20, 1990

[5] CLOTTES, J., Los chamanes de la prehistoria, Editorial Ariel, Barcelona, 2009.

[6] CORCHÓN, M. S., "Reflexiones sobre la expresión artística $\mathrm{y}$ las relaciones culturales en el magdaleiense medio cantábrico. A propósito de dos plaquitas grabadas inéditas de las Caldas (Asturias, España.)", Veleia, 24-25, PP. 175-207, (2007-2008).

[7] DELPORTE, H., La Imagen de los animales en el arte prehistórico, GEA, 1995.

[8] FORTEA, F. J., Los "Santuarios" exteriores en el paleolítico cantábrico, Complutum, 5, pp, 203-220, 1994.

[9] FORTEA, L., Estudio tecnológico de los reticulados con divisiones internas del Magdaleniense de Parpalló, Sagvntvm (P.L.A.V.), 32, pp. 51-66, 2010.

[10] FRITZ, C., La Materia del lenguaje prehistórico: el arte mueble paleolítico de Cantabria en su contexto. La aproximación teórica al arte mobiliar: a la búsqueda de un modelo social, PubliCan Ediciones, 2005.

[11] GAMBLE, C., Las sociedades paleolíticas de Europa, Editorial Ariel, Barcelona, 2001.

[12] GARCÍA, M., MARTÍN, J., GENE, J.M. Y VAQUERO, M., La plaqueta grabada del Molí del Salt (Vimbodí, Conca de Barberà) y el grafismo paleolítico/epipaleolítico en Cataluña”, Cypsela, 14, p.p. 159-174, 2002.

[13] GARCÍA, M., ROSSELL, J., VALLVERDÚ, J. Y VERGES, 
J.M., La plaqueta pintada del yacimiento epipaleolítico de Picamoixons (Alt Camp, Tarragona): aproximación al estudio de la cadena operativa, Pyrenae, 28, p.p. 25-40, 1997.

[14] GONZÁLEZ, C., Sobre la plaqueta grabada magdaleniense de la cueva de Urtiaga (Guipúzcoa). Munibe Antropología y arqueología, 36, p.p. 11-17, 1984.

[15] GUILLEM, P.M., MARTÍNEZ, R. Y MELIÀ, F., Hallazgo de grabados rupestres de estilo paleolítico en el norte de la provincia de Castellón: el Abric d'en Melià (Serra d'en Galceran)", SAGVNTVM, 33, pp. 133-140, 2001.

[16] LEWIS-WILLIAMS, D., Dentro de la mente neolítica : conciencia, cosmos y el mundo de los dioses, Ediciones Akal, Madrid, 2009.

[17] LEWIS-WILLIAMS, D., La mente en la caverna, Ediciones Akal, Madrid, 2011.

[18] MENÉNDEZ, M., Arte rupestre y arte mueble paleolítico: relaciones", Complutum 5, p.p. 343-355, 1994.

[19] MENÉNDEZ, M., La Materia del lenguaje prehistórico : el arte mueble paleolítico de Cantabria en su contexto. El mensaje es el medio, PubliCan Ediciones, 2005

[20] MOURE, J. A., Nuevas placas con representaciones de animales en el magdaleniense cantábrico", Boletín del Seminario de Estudios de Arte y Arqueología, 48, p.p. 5-24, 1982.

[21] ONTAÑÓN, R. y ARIAS, P., Congrès de l'IFRAO. Las plaquetas decoradas en los suelos de habitación magdalenienses de la Galería Inferior de La Garma (Cantabria, España), 2010.
[22] SANCHIDRIÁN, J. L., Manual de arte prehistórico, Editorial Ariel, Barcelona, 2001.

[23] SIMÓN, M. D., CORTÉS M. y BICHO, N., Primeras evidencias de arte mueble paleolítico en el sur de Portugal, Trabajos de Prehistoria, 69, pp. 7-20, 2012.

[24] SIMÓN, M. D., CORTÉS M., CLIVE J., GILES F. y RODRÍGUEZ-VIDAL J., Arte Paleolítico en Gorham's Cave (Gibraltar), Sagvntvn, 41, pp. 9-22, 2009.

[25] TOSELLO, G., La Materia del lenguaje prehistórico : el arte mueble paleolítico de Cantabria en su contexto. ¿Un contexto social para el arte mueble paleolítico en Francia?, PubliCan Ediciones, 2005.

[26] UTRILlA, P., MAZO, C., SOPENA, M.C., DOMINGO, R. Y MARTÍNEZ-BEA, M., Ríos, montañas y charcas: una representación de paisaje en el bloque 1 de la cueva de Abauntz, Veleia, 24-25, pp. 229-260, 2007-2008.

[27] UTRILLA, P. Y MAZO, C., Arte mueble sobre soporte lítico de la cueva de Abauntz. Su aportación a los estilos del magdaleniense tardío", Complutum Extra 6(1), pp. 41-62, 1996.

[28] VILLAVERDE, V., Arte paleolítico de la Cova del Parpalló: estudio de la colección de plaquetas y cantos grabados y pintado, Diputació de València, Valencia, 1994.

[29] VILLAVERDE, V., De Neandertales a Cromañones. Los inicios del poblamiento en las tierras valencianas. Arte de los cazadores y recolectores del Paleolítico superior, Universitat de València, Valencia, 2001 